\title{
On the temperature of frozen lakes
}

\section{F.-A. Forel}

To cite this article: F.-A. Forel (1880) On the temperature of frozen lakes, Philosophical Magazine, 9:56, 305-307, DOI: $10.1080 / 14786448008626843$

To link to this article: http://dx.doi.org/10.1080/14786448008626843

\section{Published online: 28 Apr 2009.}

Submit your article to this journal ๘

Џ Article views: 2 
Clarendon Press Series. A Treatise on Statics, containing the fundamental Principles of Electrostatics and Elasticity. By GEORGE M. Mrnoun, M.A. Dublin, Professor of Applied Mathematics in the Royal Indian Engineering College, Cooper's Hill. Second Edition, Corrected and Enlarged. Oxford, at the Clarendon Press, 1880. (8vo, pp. $x$ and 518.)

We noticed the first edition of this work at the time of its publication (p. 386, vol. iv. fifth series), and expressed our sense of its great merits as a comprehensive treatise on Statics. We need not, therefore, do more on the present occasion than mention the leading points in which this second edition differs from its predecessors. There are, of course, numerous minor alterations and corrections, such as those which are almost invariably required in the second edition of a mathematical work abounding in examples, or as the division of chapter 6 of the first edition into chapters 6 and 7 of the new edition. Besides these alterations there are additions of importance-such as the articles in chapter 5 , on the force polygon and the funicular polygon, and on the construction derived from them of the resultant of a given system of forces in one plane; and those on "Astatic Equilibrium," a subject on which an interesting paper was published not long ago by the author in the Proceedings of the London Mathematical Society. The most important addition, however, is chapter 16 , on what we pointed out as an omitted subject in our notice of the first edition. It treats of the Equilibrium of an Elastic Solid, and consists of three sections, viz. the "analysis of small strains," the "analysis of stresses," and the "expression of stress in terms of strain." Although the chapter runs to the length of sixty-two pages, it may be surmised that the author felt himself rather in want of space, or he would hardly have given so important a theorem as "the equation of three moments" in the form of an unworked example. However, the chapter is a most valuable addition to the work, and one that will require and repay the student's closest attention.

The present edition is issued as a volume of the Clarendon Press series, and is printed in the ordinary octavo form. The latter circumstance has greatly improved its appearance; it has also given it the air of having been greatly enlarged; but so far as we have compared the two editions this does not seem to have been the case, except so far as chapter 16 is concerned.

\section{Intelligence and Miscellaneous Articles.}

ON THE TEMPERATURE OF FROZEN LAKES. BY F.-A. FOREL.

TN 1879 some interesting thermometric soundings beneath the ice 1 of the Scotch lakes were published in 'Nature,' vol. xix. p. 421, by Mr. J. Y. Buchanan, which have considerably modified the accepted ideas upon the limit of the vertical propagation of cold in fresh water. Instead of finding at the bottom, as was expected, a layer of water with the temperature of $4^{\circ} \mathrm{C}$. (that of 
the maximum density of water), Mr. Buchanan ascertained that, in Loch Lomond, the temperature of the water gradually rose from $0^{\circ}$ at the surface to $2^{\circ} .4$ at 20 metres depth, but did not rise higher. Must we infer from this the incorrectness of the classic theory of the congelation of lakes? According to that theory, water, after cooling throughout its mass down to $4^{\circ}$ under the action of thermal convection currents, becomes colder only at the surface, being stratified in layers the colder the more superficial they are, conformably to the order of their densities. The following observations prove that the depths reached by Mr. Buchanan were not sufficient to show the limit of the superficial cooling, which descends to a much greater depth than has ever been supposed.

I have repeated these researches in some Swiss lakes which are deeper than those of Scotland. My soundings, executed with a Negretti-and-Zambra thermometer, were made in the Lake of Morat on December 23, 1879, and the Lake of Zurich on January 25, 1880 .

\section{Lake of Morat.}

(Superficies 27.4 kilometres; greatest depth 45 metres. The lake began to freeze on the 18th December. Thickness of the ice on the 23rd December, 11 centims.; on the 1st of February, 36 centims.)

\begin{tabular}{|c|c|c|c|c|}
\hline Depth. & & December 23 . & February 1. & Difference. \\
\hline $\begin{array}{c}\text { metres. } \\
0\end{array}$ & & $0 \cdot 36$ & $\stackrel{\circ}{0} \cdot 35$ & $-\stackrel{\circ}{0} \cdot 01$ \\
\hline 5 & & $1 \cdot 60$ & $1 \cdot 90$ & $+0 \cdot 30$ \\
\hline 10 & $\ldots \ldots$ & . $2 \cdot 00$ & $2 \cdot 00$ & $0 \cdot 00$ \\
\hline 15 & $\ldots \ldots$ & . $\quad 2 \cdot 23$ & $2 \cdot 45$ & +0.22 \\
\hline 20 & $\ldots$ & $2 \cdot 46$ & $2 \cdot 50$ & $+0 \cdot 04$ \\
\hline 25 & & $2 \cdot 60$ & $2 \cdot 50$ & $-0 \cdot 10$ \\
\hline 30 & $\ldots$ & $2 \cdot 66$ & $2 \cdot 40$ & -0.26 \\
\hline 35 & $\ldots \ldots$ & $2 \cdot 75$ & $2 \cdot 55$ & -0.20 \\
\hline 40 & & $2 \cdot 70$ & 2.70 & $0 \cdot 00$ \\
\hline & Ieans.. & $\overline{2 \cdot 15}$ & $\overline{2 \cdot 15}$ & \\
\hline
\end{tabular}

II. Lake of Zurich.

(Superficies 87.8 kilometres; greatest depth 141 metres. The lake froze during two days at the end of December, and then again and definitively on the 21st of January. Thickness of the ice on the 25th of January, 10 centims.)

\begin{tabular}{|c|c|c|c|}
\hline Depth. & Temperature. & Depth. & Temperature. \\
\hline $\begin{array}{c}\text { metres. } \\
0\end{array}$ & $\ldots \ldots \quad \stackrel{\circ}{0} \cdot 2$ & $\begin{array}{c}\text { metres. } \\
70\end{array}$ & $3 \cdot 7$ \\
\hline 10 & $2 \cdot 6$ & 80 & $3 \cdot 8$ \\
\hline 20 & $\ldots \ldots$ & 90 & $3 \cdot 8$ \\
\hline 30 & $3 \cdot 2$ & 100 & $3 \cdot 9$ \\
\hline 40 & $3 \cdot 5$ & 110 & $3 \cdot 9$ \\
\hline 50 & $\ldots \ldots \quad 3 \cdot 6$ & 120 & $4 \cdot 0$ \\
\hline 60 & $\ldots \ldots$ & 133 & 4.0 \\
\hline
\end{tabular}


From these numbers I draw the following conclusions :-

1. The old theory of the freezing of lakes, which assumes a progressive cooling of the whole mass down to $4^{\circ}$, and then a further lowering of the temperature of the superficial layers stratified from $0^{\circ}$ to $4^{\circ}$ according to the order of their densities, is perfectly correct.

2. The penetration of the cold into the upper layers may descend to a depth of 110 metres (Zurich).

3. It was in consequence of its comparative shallowness that Loch Lomond did not exhibit to Mr. Buchanan the temperature of $4^{\circ}$ in its bottom layers.

4. The penetration of cold into the upper layers takes place progressively and very gradually. The curve which can be drawn from my numbers from the Lake of Zurich presents neither leaps nor jerks; it is altogther analogous to the curves of superficial heating of a lake in summer. This, it seems to me, is quite sufficient to put aside the supposition that the cooling, which penetrates so deeply, takes place either by way of thermal convection or by mechanical mixture under the action of waves and currents-with the exception, perhaps, of the upper layer of from 5 to 10 metres thickness.

Must this penetration of cold be attributed to phenomena of conductivity, or to phenomena of radiation, either of the water itself or of the soil through the water? The experiments have not supplied me with any elements for answering this question.

5 . On comparing the two series of soundings made in the Lake of Morat, separated by an interval of forty days, I find that the mean temperature remained exactly the same. Therefore the layer of ice absolutely stopped the cooling of the water, and the action of the exterior cold was all expended in increasing the thickness of the ice.

6. During these forty days the water of the Lake of Morat beneath the ice underwent an equalization of temperature; the colder upper layers were warmed a little, while the warmer bottom layers were cooled; but we are still very far from finding complete uniformity of temperature in the entire depth of the lake on the 1st of February.-Comptes Rendus de l'Acad. des Sciences, Feb. 16, 1880.

ON GAS-FRICTION, AND ON THE VELOCITY OF ELECTRICITY IN

THE ELECTRIC CURRENT. BY PROF. LUDWIG BOLTZMANN.

In a memoir entitled "To the Theory of Gas-friction," the relative velocity and its longitude and latitude with respect to the relocity of one of the molecules as axis, and to the plane of the velocities of both molecules as first meridian, are introduced as integration-variables; and thereby the equation for the distribution of velocities in a moved gas is simplified. Here the velocities meant are everywhere those before impact. The determination of the coefficient of friction by the development of a series, exact account being taken of the distribution of velocities, is then encountered by no difficulty. 